\title{
Determination of Iron in Environmental Water Samples by FIA-TLS
}

\author{
Gaja Tomsič, ${ }^{1}$ Leja Goljat, ${ }^{1}$ Hana Budasheva, ${ }^{1}$ Dorota Korte ${ }^{1, \star}$ \\ Arne Bratkič ${ }^{2}$ and Mladen Franko ${ }^{1}$ \\ ${ }^{1}$ University of Nova Gorica, Laboratory for Environmental and Life Sciences, Vipavska 13, SI-5000 Nova Gorica, Slovenia \\ ${ }^{2}$ Vrije Universiteit Brussel, Boulevard de la Plaine 2, 1050 Ixelles, Bruxelles, Belgium \\ *Corresponding author: E-mail: Dorota.Korte@ung.si
}

Received: $10-30-2018$

Presented at the $24^{\text {th }}$ Annual Meeting of the Slovenian Chemical Society

\begin{abstract}
The determination of low concentration of iron in natural waters can be difficult due to the complexity of natural water, but primarily because it requires preconcentration of the sample with solvent extraction. In this work we report on results of thermal lens spectrometry (TLS) coupled to flow injection analysis (FIA) as a highly sensitive FIA-TLS method of iron detection. The concentration of iron redox species was determined using 1,10-phenanthroline (PHN), that forms stable complexes with $\mathrm{Fe}(\mathrm{II})$ ions which are characterized by an absorption maximum at $508 \mathrm{~nm}$. The TLS system using a $633 \mathrm{~nm}$ probe laser and $530 \mathrm{~nm}$ pump laser beam was exploited for on-line detection in flow injection analysis, where a PHN solution was used as the carrier solution for FIA. The concentration of the complexing agent affects the quality of the TLS signal, and the optimal concentration was found at $1 \mathrm{mM} \mathrm{PHN}$. The achieved limits of detection (LODs) for $\mathrm{Fe}(\mathrm{II})$ and total iron were $33 \mathrm{nM}$ for $\mathrm{Fe}(\mathrm{II})$ and $21 \mathrm{nM}$ for total iron concentration. The method was further validated by determining the linear concentration range, specificity in terms of analytical yield and by determining concentration of iron in a water sample from a local water stream.
\end{abstract}

Keywords: Flow injection analysis; iron concentration; thermal lens spectrometry

\section{Introduction}

As the fourth most frequent element in the earth's crust, iron is a geologically important element. As a trace element iron is also present in the biosphere in organisms, where it performs key life functions.

Iron can be found in various forms in water: as dissolved, colloidal or particulate, either in the elemental form or in bivalent or trivalent ion forms, and in complexes. ${ }^{1}$ The abundance of each species depends on the $\mathrm{pH}$ and Eh values of the aquatic environment. The oxidation state of iron affects the properties of the species, mobility and accessibility to organisms. At $\mathrm{pH}$ around 8 , iron can be found as $\mathrm{Fe}(\mathrm{II})$ and $\mathrm{Fe}(\mathrm{OH})_{3}$. In the reductive conditions, the prevalent oxidation state is the divalent ion form $\mathrm{Fe}(\mathrm{II})$, which is soluble in water. In oxidative conditions, however, $\mathrm{Fe}(\mathrm{II})$ is oxidized to $\mathrm{Fe}(\mathrm{III})$. It forms insoluble hydroxides, $\mathrm{Fe}(\mathrm{OH})_{3}$. Due to this phenomenon, the concentration of iron in natural water is very low.
In fresh waters as rivers, lakes, groundwater and drinking water, iron is found at trace amounts. Compared with seawater, fresh water is richer in $\mathrm{Fe}(\mathrm{II})$ ions. Iron concentrations in fresh water can vary greatly depending on the source of water, its tributaries and other external circumstances. The World Health Organization, which operates within the United Nations, reports that the average iron concentration in rivers is around $14 \mu \mathrm{M} .^{2}$ In anaerobic conditions, iron concentrations may be higher, between 9-190 $\mu \mathrm{M}$. The highest possible values may reach up to $893 \mu \mathrm{M}$. In drinking water iron concentrations are usually lower, less than $5 \mu \mathrm{M}$. In Slovenian rivers, the concentration of soluble iron species reaches up to $13 \mu \mathrm{M} .^{3}$ The lowest concentrations are lower than the limit of quantification of methods nowadays widely used as colorimetric analysis with UV-VIS detection, atomic absorption spectroscopy, chemiluminescence. In groundwater iron concentrations are significantly lower than the concentrations measured in rivers. ${ }^{4}$ Generally, the concentrations of iron 
in groundwater are below $0.2 \mu \mathrm{M}$, but sometimes can be even lower than $2 \mathrm{nM}$. As a result, lower concentrations of iron are also found in drinking water. The limit value of iron in drinking water is $4 \mu \mathrm{M},{ }^{5}$ but this value is rarely exceeded, as iron concentrations in surface waters exploited as drinking water sources reach only up to $0.7 \mu \mathrm{M}$, with a mean value of about $0.2 \mu \mathrm{M}^{6}$

In certain ocean areas dissolved iron concentrations can be as low as $20-30 \mathrm{pM}$, so that iron represents a limiting factor in the growth of microorganisms. ${ }^{7-11}$ It was observed that already at $1.3 \mathrm{nM}$ concentration of iron in water or lower, the growth of biomass is slowing down. ${ }^{11}$

Without the environmentally available iron marine and freshwater organisms cannot perform their metabolic functions, since iron participates in the photosynthetic process, cellular respiration, nitrate reduction and the synthesis of chlorophyll. ${ }^{7}$ The content of iron in the aquatic environment, even if it is usually low, therefore, affects the functioning of organisms, as it enables or impedes their growth. This can have an impact on the entire ecosystem. ${ }^{12}$ The amount of algae in marine waters can play an important role in the fixation of atmospheric carbon dioxide in sea biomass. Consequently, the increased biomass growth and photosynthesis reduces the amount of carbon dioxide in the atmosphere, which represents an important sink for this greenhouse gas.

In order to assess the status of an aquatic system, one of the key data that must be at disposal is the bioavailability of iron. Chemical analysis of natural water is a challenging task. UV-VIS spectrometry is a technique often used to determine the concentration of iron species in liquid samples after the complexation with 1,10-phenanthroline (PHN) and formation of an orange-coloured complex. This is a simple method, yet it has a major disadvantage, i.e. the limited sensitivity. Measurement of very low iron concentrations by UV-VIS is therefore impeded. For this reason, a number of other techniques for determining iron concentration in water samples were developed. The methods are as flow injection analysis coupled with spectrophotometric detection and on line preconcentration using a column filled with 8 -hydroxyquinoline resin ${ }^{13}$ or inductively coupled plasma mass spectrometry, ${ }^{14,15}$ laser-induced breakdown spectroscopy, ${ }^{16}$ flow injection chemiluminometric method ${ }^{17}$ and for lowest concentrations rely on preconcentration. In all cases, the aim is to maximize the sensitivity of the technique while simultaneously simplifying the system. The method should be user-friendly and inexpensive, but must provide reliability, high sensitivity and good repeatability. Furthermore, an increasing emphasis is nowadays put on environmental protection by developing methods that use as little harmful chemicals as possible. Recently, TLS which is known as one of the most sensitive spectrometric methods for the analysis of liquid samples, and enables detection of absorbances as low as $10^{-7}$ absorption units, ${ }^{18}$ was developed and optimized to provide a high throughput platform for highly sensitive and environmentally friendly analysis of water and other samples. ${ }^{19}$

The main aim of this study was to develop an efficient, fast and reliable method for determination of low concentrations of iron species in natural water based on TLS technique coupled to flow injection analysis (FIA). The performances of FIA-TLS technique (LOD, linear range, specificity) were evaluated and the achieved LODs were compared to UV-VIS spectrometry, after establishing the optimal conditions for FIA-TLS determination of $\mathrm{Fe}(\mathrm{II})$ and $\mathrm{Fe}(\mathrm{III})$ species.

\section{Experimental}

\section{1. Reagents and Solutions}

Double deionized ultrapure Milli-Q-water (MQ) water $\left(18 \mathrm{M} \Omega \mathrm{cm}^{-1}\right)$ was used for preparation of the initial solutions and for their dilution. The MQ water was obtained with the NANOpure double deionization system (Barnstead, Thermo Scientific). The following chemicals were used without further purification:

- Hydrochloric acid, $\mathrm{HCl}$ (p.a., 32\%, Carlo Erba reagents)

- Acetic acid, $\mathrm{CH}_{3} \mathrm{COOH}$ (puriss. p.a., $\geq 99,8 \%$, Sigma-Aldrich)

- Ascorbic acid, $\mathrm{C}_{6} \mathrm{H}_{8} \mathrm{O}_{6}$ (reagent grade, 99\%, Sigma)

- 1,10-phenanthroline (reagent grade, 99\%, Alfa Aesar)

- Ferrous sulphate heptahydrate, $\mathrm{FeSO}_{4} \cdot 7 \mathrm{H}_{2} \mathrm{O}$ (ACS grade, 99,5\%, Merck)

- Ferric chloride hexahydrate, $\mathrm{FeCl}_{3} \cdot 6 \mathrm{H}_{2} \mathrm{O}$ (puriss. p.a., $\geq 99.5 \%$, Riedel-de Haën)

Iron detection was enabled by a colorimetric reaction with PHN, that binds Fe(II) ions and forms a stable $\left[\mathrm{Fe}(\mathrm{PHN})_{3}\right]^{2+}$ complex with an absorption maximum at $508 \mathrm{~nm}$. The total iron was determined by reducing $\mathrm{Fe}(\mathrm{III})$ ions to $\mathrm{Fe}(\mathrm{II})$ in the presence of ascorbic acid, since only the redox form of $\mathrm{Fe}(\mathrm{II}) \mathrm{can}$ form a $\left[\mathrm{Fe}(\mathrm{PHN})_{3}\right]^{2+}$.

For the UV-VIS spectrophotometric measurements all the working standard solutions $(5-100 \mu \mathrm{M})$ were prepared by adding $1 \mathrm{~mL}$ of $30 \mathrm{mM}$ PHN solution to the corresponding volume of the stock standard solution of 0.01 $\mathrm{M} \mathrm{Fe}(\mathrm{II})$, and diluting to $10 \mathrm{~mL}$ by deionised water in a volumetric flask. $1 \mathrm{~mL}$ of $0.03 \mathrm{mM}$ solution of ascorbic acid was added to the solutions containing Fe(III) ions before adding $30 \mathrm{mM}$ PHN.

For the FIA-TLS measurements the working standard solutions were prepared in the range of $1-20 \mu \mathrm{M}$ by proper dillution of stock standard solution by deionized $\mathrm{H}_{2} \mathrm{O} .1 \mathrm{mM}$ PHN solution, which was made $0.03 \mathrm{mM}$ with respect to ascorbic acid to reduce $\mathrm{Fe}(\mathrm{III})$ was used as carrier solution for Fe determination. In optimization experiments the PHN concentrations from $30 \mathrm{mM}$ to $0.5 \mathrm{mM}$ were tested. 
The $\mathrm{pH}$ of analysed solutions was found to be in the optimum $\mathrm{pH}$ range for the complexation reaction (between 6 and 9), thus, did not required further adjustment.

The analysed real samples were water samples from Vrtojbica creek. The samples were measured as collected without any pre-treatment.

\section{2. Measurement Techniques}

\section{2. 1. UV-VIS Spectrophotometry}

The PerkinElmer Lambda 650 S UV-VIS dual beam spectrometer was used to measure the absorbances of working standard solutions and for recording the absorption spectra, in the wavelengths' range between $400 \mathrm{~nm}$ and $650 \mathrm{~nm}$. All measurements were performed in a 10 mm optical path quartz cuvette (HELLMA, model 100QS) with respect to blank solution, that contained all added reagents to the working standard solutions except for iron.

\section{2. 2. Thermal Lens Spectrometry with Flow Injection Analysis}

The scheme of the FIA-TLS experimental setup is shown in Figure 1. The sample is irradiated by laser light from Innova 70 Coherent Ar-ion laser with output wavelength of $514.5 \mathrm{~nm}$, providing $150 \mathrm{~mW}$ power at the sample (excitation beam, EB). EB is modulated using a mechanical modulator (Scitec instruments, Control unit model 300C, chopping head model 300CD, chopping disks model $300 \mathrm{H}$ ). The selected frequency was $30 \mathrm{~Hz}$, as this ensured the maximum signal-to-noise ratio (for frequencies $\leq 10 \mathrm{~Hz}$ the mechanical chopper did not provide stable modulation frequency). The absorbed energy is converted into heat and as a result, the refractive index of the sample is changed, and a thermal lens (TL) is formed in the sample. The TL is detected by the use of another laser beam - the probe beam $(\mathrm{PB})$ from a He-Ne laser (Uniphase, Model 1103P) with output wavelength of $633 \mathrm{~nm}$ and output power of $2 \mathrm{~mW}$. PB is defocused by TL resulting and its intensity change is measured by a photodiode (Thorlabs, model PDA 36A-EC) and converted into voltage registered by the lock-in voltage amplifier (Stanford Research Instruments, the SR830 DSP model) and collected by Mathlab software. The recorded change in the PB intensity depends linearly on the concentration of absorbing species in the sample.

The flow injection unit (FIA) consisted of an HPLC pump (Knauer Advanced Scientific Instruments) used to deliver the carrier solution (PHN) and the sample to the detection cell. The working standard solutions and the sample (different concentration of iron ions) are injected through the metal free injection valve (RHEODYNE, model 7725) equipped with a $10 \mu \mathrm{L}$ peek sample loop (CHEMINERT, VICI). The carrier solution flow rate of 0.6 $\mathrm{mL} \mathrm{min}{ }^{-1}$ is used and the TLS detection is performed in a

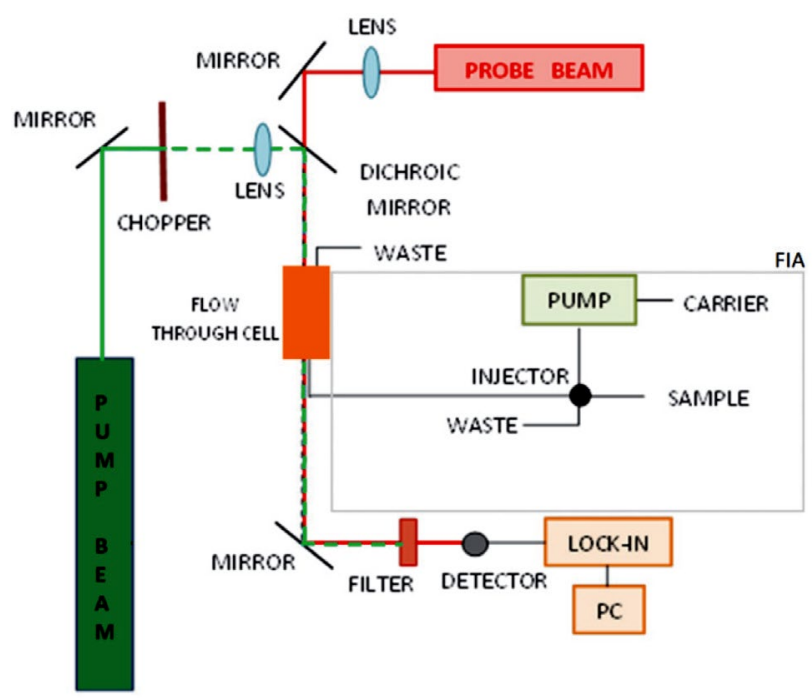

Figure 1. Scheme of the FIA-TLS experimental setup adopted from [20]

$10 \mathrm{~mm}$ pathlength $(8 \mu \mathrm{L})$ flow through detection cell (HELLMA, model 178.173-QS) in which the TL was induced upon irradiation by the EB.

\section{Results and Discussion}

\section{1. UV-VIS Spectrophotometry}

In the first step the absorption spectra of $\left[\mathrm{Fe}(\mathrm{PHN})_{3}\right]^{2+}$ solutions were recorded at different concentrations of the complex (Figure 2). The absorption maximum was found at $508 \mathrm{~nm}$.

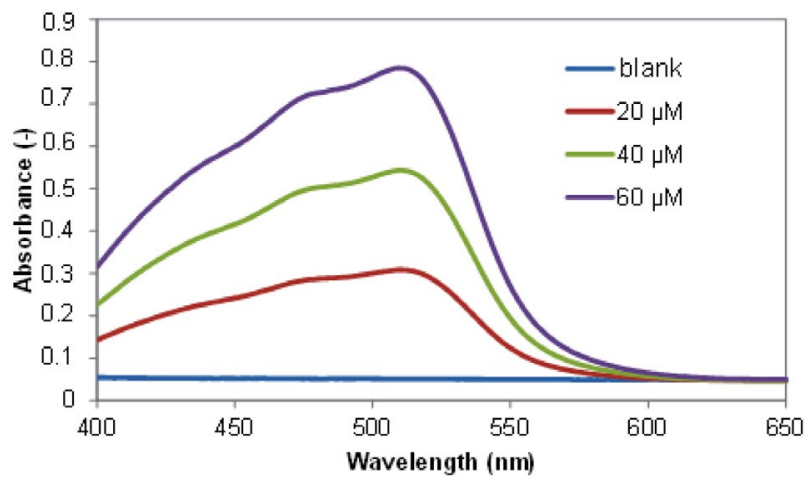

Figure 2. Absorption spectra of $\left[\mathrm{Fe}(\mathrm{PHN})_{3}\right]^{2+}$ complex for different $\mathrm{Fe}(\mathrm{II})$ concentration

Next, the calibration curves for Fe(II) and Fe(III) determination were constructed in the $5 \mu \mathrm{M}-100 \mu \mathrm{M}$ concentration range (Figure 3 ).

The obtained relationship between absorbance and concentration shows good linearity $\left(\mathrm{R}^{2}>0.995\right)$ over the investigated concentration range $(0$ to $100 \mu \mathrm{M})$ for $\mathrm{Fe}(\mathrm{II})$ and $\mathrm{Fe}$ (III) ions (Figure 3). The limit of detection (LOD) is calculated as the concentration giving a signal that is three 


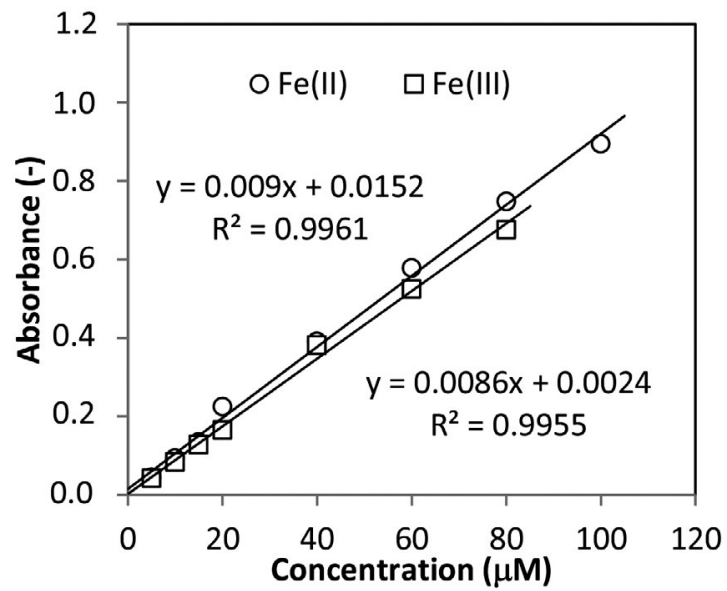

Figure 3. Calibration curves for $\mathrm{Fe}(\mathrm{II})$ and $\mathrm{Fe}(\mathrm{III})$ determination by UV-VIS spectrophotometry

times larger than the standard deviation of blank signal (Equation 1).

$$
L O D=\frac{3 * S D_{0}}{k},
$$

Where LOD is the limit of detection, $S D_{0}$ standard deviation of blank signal and $k$ the slope of the calibration line.

The calculated LODs were $130 \mathrm{nM}$ for $\mathrm{Fe}(\mathrm{II})$ and 135 $\mathrm{nM}$ for $\mathrm{Fe}$ (total). The concentration of total iron was determined on the basis of calibration line for $\mathrm{Fe}(\mathrm{II})$, since $\mathrm{Fe}(\mathrm{III})$ was reduced to $\mathrm{Fe}(\mathrm{II})$ by ascorbic acid. The concentration of $\mathrm{Fe}(\mathrm{III})$ was then calculated as difference between the concentration of total iron and Fe(II).

\section{2. Thermal Lens Spectrometry with Flow Injection Analysis}

Different concentration of the complexing agent $(\mathrm{PHN})$ in the carrier were examined in the study. In case of $30 \mathrm{mM}$ PHN solution (as used for the measurement by UV-VIS spectrophotometry) incomplete mixing of the

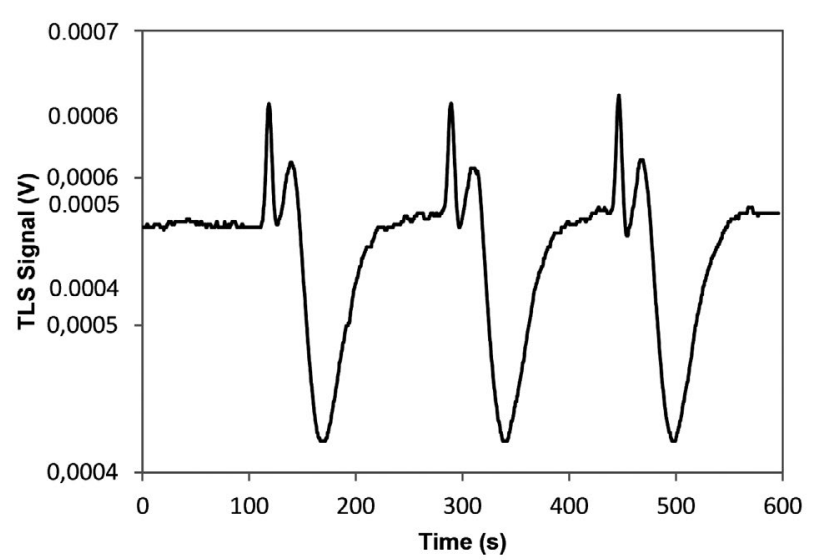

Figure 4. The shape of FIA-TLS signal peaks for $30 \mathrm{mM}$ PHN used as a carrier solution carrier and sample solutions was observed in the form of disturbance in the signal peaks which are the consequence of inhomogeneous refractive index of solution in the mixing area (Figure 4$)^{21}$

As the problem could not be solved using a mixing coil between the injector and the sample cell, the concentration of $\mathrm{PHN}$ in the carrier solution was reduced to make the carrier and sample solutions as similar as possible in their composition. Thus, the PHN concentration was reduced from $30 \mathrm{mM}$ to $10 \mathrm{mM}, 5 \mathrm{mM}, 2 \mathrm{mM}, 1 \mathrm{mM}$ and $0,5 \mathrm{mM}$.

The changes in shape of FIA-TLS signal peaks are presented in Figure 5. It is observed, that with decrease in PHN concentration the mixing problems disappear, but the height of the measured signal peak also decreases. This is related to the fact that in the case of lower reactant concentrations the reaction rate decreases, which means that in the same time interval not all Fe(II) ions are complexed by $\mathrm{PHN}$ to form $\left[\mathrm{Fe}(\mathrm{PHN})_{3}\right]^{2+}$ complex. At concentrations of PHN as low as $0.5 \mathrm{mM}$, the value of the TLS signal at its peak is 3.5 times lower compared to $2 \mathrm{mM}$ PHN.

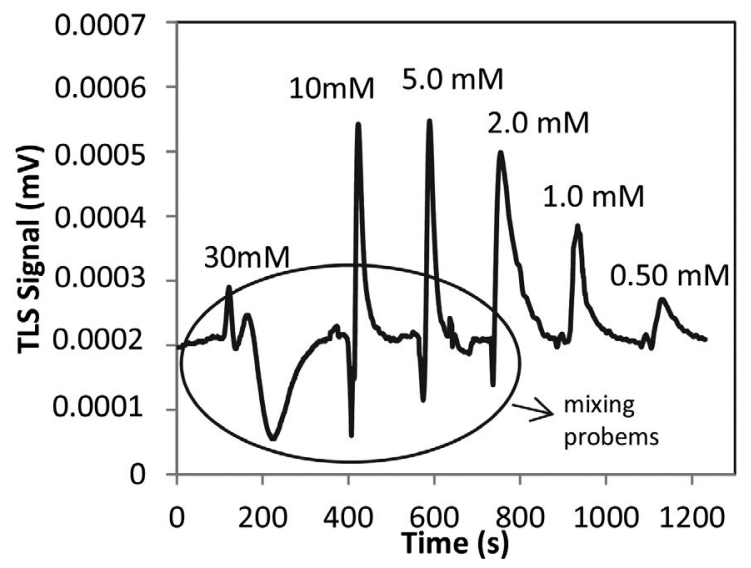

Figure 5. The shape of TLS signal peaks for different concentrations of PHN in carrier solution

Figure 5 shows, that for 1.0 and $0.5 \mathrm{mM}$ PHN-related peaks mixing of the carrier and the sample have no significant effect on the peak heights, as there is no sharp decrease of the TLS signal before the peak, as observed at higher PHN concentrations. In these two cases the concentration of PHN is sufficiently low to provide similar composition of carrier solution and the sample in terms of refractive index. Unfortunately, as it is seen in Figure 5, the decrease of the TLS signal peak heights at lower PHN concentrations in the carrier decreases the sensitivity and increases the LOD of the method.

Thus, for FIA-TLS measurements, $1 \mathrm{mM}$ was chosen as the optimal PHN concentration in the carrier solution, since it provided the highest sensitivity among tested carrier solutions and conditions where no effects on TLS signal due to mixing problems were observed. The peaks of TLS signal for $\mathrm{Fe}(\mathrm{II})$ and $\mathrm{Fe}(\mathrm{III})$ for $1 \mathrm{mM}$ PHN solution 
used as carrier are shown in Figures 6 and 7, respectively. The constructed calibration lines for Fe(II) and Fe(III) concentration are presented in Figure 8. Good agreement of the slopes confirms that the reduction of Fe(III) is quantitative under given experimental conditions.

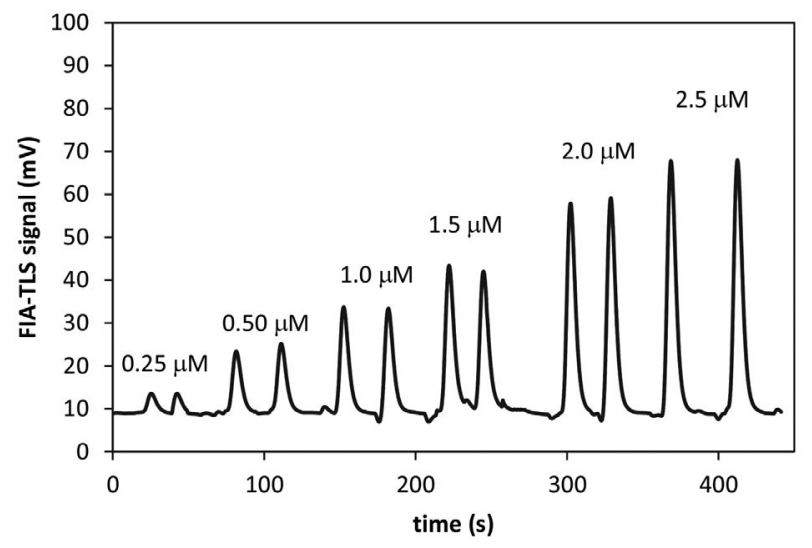

Figure 6. The TLS signal peaks of Fe(II) with $1 \mathrm{mM}$ PHN as carrier solution

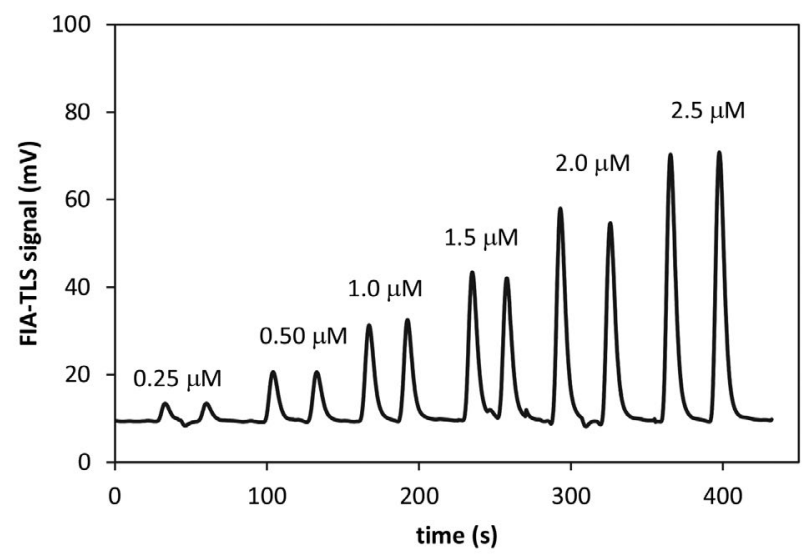

Figure 7. The TLS signal peaks of $\mathrm{Fe}(\mathrm{III})$ with $1 \mathrm{mM}$ PHN as carrier solution

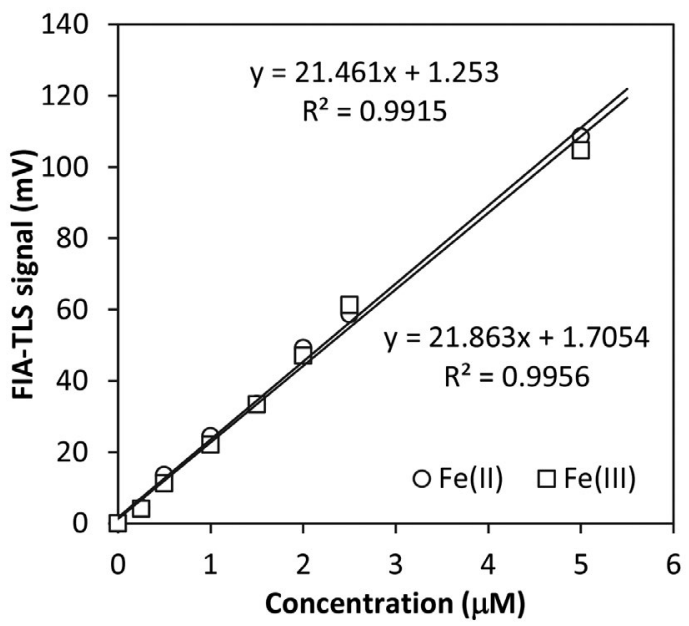

Figure 8. Calibration curve for determination of $\mathrm{Fe}(\mathrm{II})$ and $\mathrm{Fe}(\mathrm{III})$ by FIA-TLS with $1 \mathrm{mM}$ PHN as carrier solution
The linear range of the method (defined as the range of independent variable for which strong linear relationship exists between the iron concentration and the FIATLS signal) is between $0.2-5 \mu \mathrm{M}$ for $\mathrm{Fe}(\mathrm{II})$ and $0.2-2.5 \mu \mathrm{M}$ for $\mathrm{Fe}(\mathrm{III})$ and the calculated LODs were $15 \mathrm{nM}$ and 13 $\mathrm{nM}$ for $\mathrm{Fe}(\mathrm{II})$ and $\mathrm{Fe}$ (total), respectively.

The effect of PHN concentration on the sensitivity of the FIA-TLS method was investigated further by performing the complexation reaction off-line and using just water as the carrier. In this case final dilution was made to $50 \mathrm{~mL}$ and $30 \mathrm{mM}$ PHN could be used as reagent added to the sample. The final concentration of PHN in the sample was therefore similar $(0.6 \mathrm{mM})$ as used in the carrier in case of FIA-TLS to avoid mixing problems. As can be seen on Figure 9, no distortions of the peaks due to mixing are observed. Figure 9 also shows significant difference in sensitivity, as can be deduced by comparison of TLS signal peak heights to those recorded in case of FIA-TLS with on-line complexation reaction (Figures 6 and 7), which is in fact five times lower due to use of lower PHN concentration. LODs of $3 \mathrm{nM}$ were achieved for $\mathrm{Fe}$ (II) and $\mathrm{Fe}$ (total) by of-line complexation of $\mathrm{Fe}(\mathrm{II})$ and TLS detection in FIA mode.

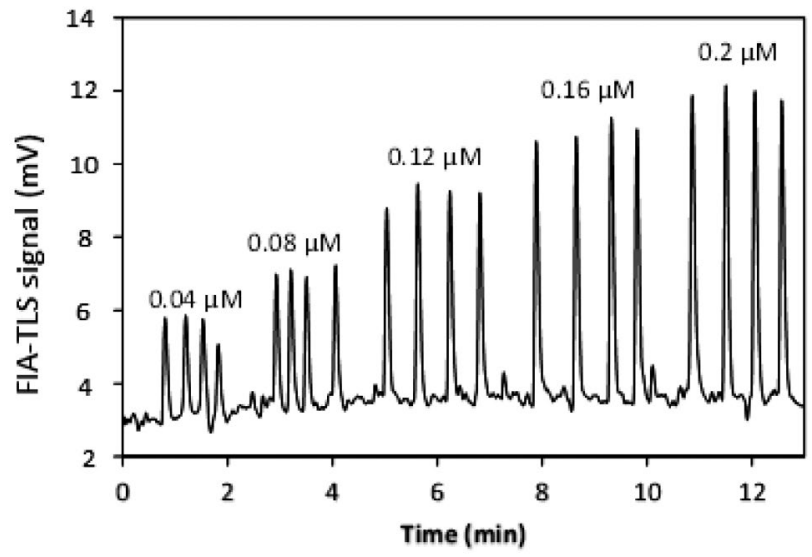

Figure 9. FIA-TLS signals for replicate injections of $\left[\mathrm{Fe}(\mathrm{PHN})_{3}\right]^{2+}$ at different concentrations

To verify the method, concentration of iron species in real samples was determined by standard addition method. The examined sample was the water from Vrtojbica creek, which was spiked by Fe(II) standard (for determination of $\mathrm{Fe}(\mathrm{II})$ ) or by $\mathrm{Fe}(\mathrm{III})$ standard (for determination of Fe(total)) solutions at $0.5 \mu \mathrm{M}, 1 \mu \mathrm{M}, 2 \mu \mathrm{M}, 3 \mu \mathrm{M}$ and $4 \mu \mathrm{M}$ levels. Figure 10 shows the FIA-TLS signals for original water sample and signals for samples with different standard additions of $\mathrm{Fe}$ (III). The complexity of the medium affected the limit of detection, which was $373 \mathrm{nM}$ for $\mathrm{Fe}(\mathrm{II})$ and $314 \mathrm{nM}$ for $\mathrm{Fe}(\mathrm{III})$ determination. This is approximately 25 times higher than for the Fe(II) and $\mathrm{Fe}(\mathrm{III})$ in deionized water.

Vrtojbica creek contained $1.43 \mu \mathrm{M} \pm 0.15 \mu \mathrm{M} \mathrm{Fe}$ (II), which corresponds to $80 \mu \mathrm{g} / \mathrm{L} \pm 8 \mu \mathrm{g} / \mathrm{L}$, as well as $1.90 \mu \mathrm{M}$ 


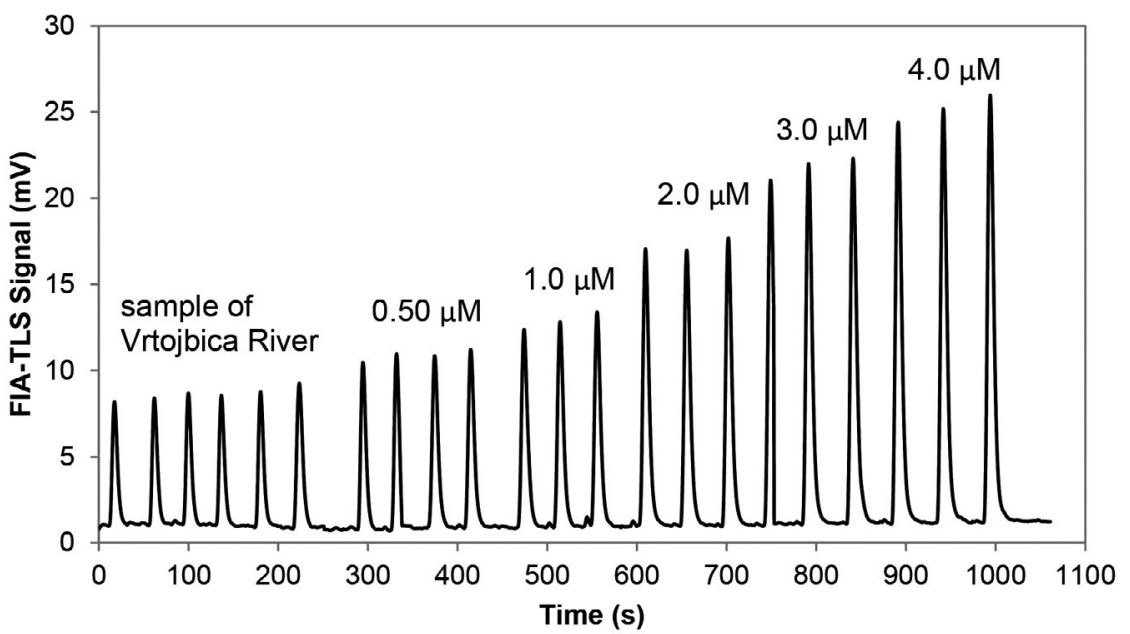

Figure 10. The TLS signal peaks of Vrtojbica creek with added proper amount of Fe(III) and $1 \mathrm{mM}$ PHN as carrier solution

$\pm 0.12 \mu \mathrm{M}$ total iron, which corresponds to $106 \mu \mathrm{g} / \mathrm{L} \pm 7$ $\mu \mathrm{g} / \mathrm{L}$. From the subtraction of the concentration of Fe(II) from the measured value of total iron concentration, the concentration of $\mathrm{Fe}(\mathrm{III})$ was found to be $26 \mu \mathrm{g} / \mathrm{L} \pm 8 \mu \mathrm{g} / \mathrm{L}$.

These results correspond within the measurements uncertainity to those determined by external calibration.

In the next step the analytical yield of the method was determined as a ratio of the measured and actually added concentration of the analyte in the examined sample solution. The results are presented in Table 1.

Table 1. The analytical yield of the FIA-TLS method for determination of total iron added as Fe(III)

\begin{tabular}{cccc}
\hline $\begin{array}{c}\text { Added } \\
\text { concentration } \\
(\mu \mathrm{M})\end{array}$ & $\begin{array}{c}\text { Measured } \\
\text { concentration } \\
(\mu \mathrm{M})\end{array}$ & SD $(\mu \mathrm{M})$ & Yield (\%) \\
\hline 1.0 & 1.02 & 0.20 & $102 \pm 10$ \\
5.0 & 4.37 & 0.28 & $88 \pm 5$ \\
0.50 & 0.55 & 0.07 & $110 \pm 3$ \\
3.0 & 3.16 & 0.15 & $105 \pm 3$ \\
\hline
\end{tabular}

The results show, that the analytical yield of the method is satisfactoty and in agreement with US-EPA recommendations for acceptable analytical yields in the range of $80-120 \%$ for determination of metals and trace elements in water. ${ }^{22}$

The results obtained by the use of FIA-TLS technique were compared to those obtained by UV-VIS spectropho-

Table 2. Comparison of LODs for determination of $\mathrm{Fe}(\mathrm{II})$ and $\mathrm{Fe}$ (III) by FIA-TLS and UV-VIS spectrophotometry

\begin{tabular}{ccc}
\hline & $\boldsymbol{F e}($ II $)$ & $\mathbf{F e}($ III) \\
\hline UV-VIS & $130 \mathrm{nM}$ & $135 \mathrm{nM}$ \\
FIA-TLS & $15 \mathrm{nM}$ & $13 \mathrm{nM}$ \\
\hline
\end{tabular}

tometry. The value of LODs achieved by these two methods are compared in Table 2. The LODs achieved by FIATLS are up to 10 times lower than those achieved by UV-VIS spectrophotometry.

\section{Conclusion}

In this study iron redox species concentration was determined by thermal lens spectrometry coupled to flow injection analysis (FIA-TLS).

The technique was optimised regarding the concentration of the complexing agent used as the carrier solution. The optimal concentration of $\mathrm{PHN}$ is $1 \mathrm{mM}$, as in this way we avoid mixing problems between the sample solution and the carrier.

Furthermore, the use of the FIA-TLS method significantly reduces the amount of sample consumption. By using UV-VIS spectrophotometry approximately $3 \mathrm{~mL}$ of the sample was used for the final measurement, while with FIA-TLS the amount was $20 \mu \mathrm{L}$, what is 150 times lower.

The achieved LOD is much lower compared to those achieved for spectrophotometric method (1.07 uM ; in 10 $\mathrm{cm}$ long sample cell), thermal lens microscopy (TLM) in batch mode $(0.01 \mathrm{uM})$ and compared to values achieved by TLM-uFIA $(36 \mathrm{nM})$. $^{23-24}$

The applicability of FIA-TLS technique was verified by determining iron species concentrations in a real freshwater sample from Vrtojbica creek. The concentration of iron in Vrtojbica creek was determined by the standard addition method. It was found, that Vrtojbica creek contains $80 \mu \mathrm{g} / \mathrm{L}$ of Fe(II) and $26 \mu \mathrm{g} / \mathrm{L}$ of Fe(III). The total iron content was therefore $106 \mu \mathrm{g} / \mathrm{L}$, which fully corresponds to the values of iron in Slovenian water streams, that range from less than $1 \mu \mathrm{g} / \mathrm{L}$ to $750 \mu \mathrm{g} / \mathrm{L}$.

On the basis of the presented results it was it can be concluded that the optimized FIA-TLS technique has several advantages over other methods used for determina- 
tion of metals in liquid samples. These are in particular high sensitivity and low LODs without the need of sample preconcentration, low consumption of reagents and online detection, consequently reducing also the possible contamination.

\section{References}

1. Rich, H. W., Morel, F. M. M., Limnol. Oceanogr. 1990, 35, 652-662. DOI:10.4319/lo.1990.35.3.0652

2. WHO. 2003. Iron in Drinking-water; Background document for development of WHO Guidelines for Drinking-water Quality. Geneva.

3. ARSO. 2017. Reke-izpis podatkov za leto 2017.

4. ARSO. 2017. Podzemne vode-izpisi podatkov za leto 2017.

5. Uradni list RS, Št 19/2004. 2004. Pravilnik o pitni vodi.

6. ARSO. 2017. Površinske vode, ki se odvzemajo za oskrbo s pitno vodo.

7. Kuma, K. Biogeochemistry of iron in seawater. Report on Amur-Okhotsk Project No.2, 2004.

8. Archer, D. E., Johnson, K., Global Biogeochem. cycles. 2000, 14, 269-279. DOI:10.1029/1999GB900053

9. Anderson, M. A., Morel, F. M. M., Limnol. Oceanogr. 1982, 27, 789-813. DOI:10.4319/lo.1982.27.5.0789

10. Wells, M. L., Price, N. M., Bruland, K. W., Mar. Chem. 1995, 48, 157-182. DOI:10.1016/0304-4203(94)00055-I

11. Boye, M., van den Berg, C. M. G. , Mar. Chem. 2000, 70, $277-$ 287. DOI:10.1016/S0304-4203(00)00032-3

12. Kinnan, M. K. Determination of Iron(II) Concentrations in Seawater Using Flow Injection Analysis and Chemiluminescence. University of North Florida. 2003.
13. Laës, A., Vuillemin, R., Leilde, B., Sarthou, G., BournotMarec, C., Blain, S., Mar. Chem. 2005, 97, 347-356.

DOI:10.1016/j.marchem.2005.06.002

14. de Jong, J., Schoemann, V., Lannuzel, D., Tison, J., Mattielli, N., Anal. Chim. Acta. 2008, 623, 126-139.

DOI:10.1016/j.aca.2008.06.013

15. Milne, A., Landing, W., Bizimis, M., Morton, P., Anal. Chim. Acta. 2010, 665, 200-207. DOI:10.1016/j.aca.2010.03.027

16. Nakamura, S., Ito, Y., Sone, K., Hiraga, H., Kaneko, K., Anal. Chem.1996, 68(17) 2981-2986. DOI:10.1021/ac9601167

17. Worsfold, P. J., Lohan, M. C., Ussher, S. J., Bowie, A. R., Mar. Chem. 2014, 166, 25-35.

DOI:10.1016/j.marchem.2014.08.009

18. Franko, M., Tran, C. D., in: R.A. Meyers (Ed.): Encyclopedia of Analytical Chemistry, John Wiley \& Sons Ltd., 2010.

19. Liu, M., Malovrh, S., Franko, M., Anal. Methods 2016, 8, 5053-5060. DOI:10.1039/C6AY00932H

20. Korte, D., Grahovac, A., Jerkič, A., Vajdle, O., Anojčič, J., Guzsvany, V., Budič, B., Franko, M., Pharm. Anal. Acta. 2018, 9, 1-10.

21. Madžgalj, A., Baesso, M.L., Franko, M., Eur. Phys. J. Special Topics 2008, 153, 503-506.

DOI:10.1140/epjst/e2008-00494-4

22. EPA, Guidance for Methods Development and Methods Validation for the Resource Conservation and Recovery Act (RCRA) Program, 2012.

23. De Assis Gonsalves A., Melo Araujo C. R., Galhardo C. X., Fonseca Goulart M. O., De Abreu F. C., Am. J. Anal. Chem. 2011, 2, 776-782. DOI:10.4236/ajac.2011.27089

24. Cabrera H. Korte D., Franko M., Int. J. Thermophys. 2015, 36, 2434-2439. DOI:10.1007/s10765-015-1933-0

\section{Povzetek}

Določevanje železa v naravnih vodah je pogosto oteženo zaradi nizkih koncentracij analita in kompleksnosti naravne vode, kar zahteva predkoncentracijo vzorca $z$ ekstrakcijo. V tem delu poročamo o razvoju nove, visoko občutljive FIATLS metode za določevanje redoks specij železa brez predkoncentracije, ki temelji na uporabi spektrometrije s toplotnimi lečami (TLS), sklopljene s pretočno injekcijsko analizo (FIA). Koncentracije železa (Fe(II), Fe-skupno) smo določali po kolorimetrični reakciji z 1,10-fenantrolinom (PHN), ki kompleksira železove Fe(II) ione v stabilen kompleks z absorpcijskim maksimumom pri $508 \mathrm{~nm}$. Spektrometer TLS s tipalnim laserskim snopom valovne dolžine $633 \mathrm{~nm}$ in vzbujevalnim laserskim snopom valovne dolžine $530 \mathrm{~nm}$ smo uporabili za detekcijo v sistemu FIA, kjer je nosilna raztopina vsebovala PHN, in pri določevanju skupnega železa tudi askorbinsko kislino za redukcijo Fe(III).

Visoka koncentracija PHN v nosilni raztopini $(30 \mathrm{mM})$ negativno vpliva na višino in obliko TLS signalov za injicirane vzorce. Ugotovili smo, da je optimalna koncentracija PHN $1 \mathrm{mM}$ in z njo dosegli meji zaznave (LOD) $33 \mathrm{nM}$ za Fe(II) in $21 \mathrm{nM}$ za skupno koncentracijo železa. Metodo smo validirali še z določitvijo linearnega koncentracijskega območja, specifičnosti v smislu analitskega izkoristka in $\mathrm{z}$ določitvijo koncentracije železa v vzorcu naravne površinske vode.

Except when otherwise noted, articles in this journal are published under the terms and conditions of the Creative Commons Attribution 4.0 International License 